\title{
Tourism awareness of merchant souvenirs in Bukittinggi City
}

\author{
Wirdatul 'Aini' ${ }^{1}$, Ismaniar' ${ }^{2}$, Hayatunnufus ${ }^{3}$ \\ 123Universitas Negeri Padang, Padang - Indonesia, (wirdatul.aini@yahoo.co.id)
}

\begin{abstract}
The purpose of the study is described about tourism awareness and learning of souvenir merchants. The research approach used is qualitative. The subject is souvenir merchant which determined by the government. Data collection techniques used were observations and conducted interviews with merchants souvenir. Interviews were conducted by the people who were around them. Especially, who knew their participation for advancing the tourism area. The research findings are: (1) the description about tourism awareness of souvenir merchant, a part of them were giving the suggestion to increase the security in tourist area, (2) a small number of them was participated in maintaining the cleanliness facilities, maintaining the orderliness, cleanliness of the tourist area as a market, (3) a small number of them, less on serving the customers well, and less pacakaged product, (4) Just a little program available to learn the tourism awareness of them conducted by the government.
\end{abstract}

Keywords: tourism, awareness, souvenirs, merchant

\section{Introduction}

Tourism is currently very crowded because people talk about developing the tourism sector then the effect on the other sectors is very big, therefore the tourism demand will increasingly grow in line with the levels of human needs of the importance of travel (travelling) in order to make us fresh back after work. The more advanced a society is, the more busy recreational needs someone perceived as a basic requirement which must be met in order of physical freshness and spiritual harmony.

In 1999, contained GBHN that tourism development continues on the increase and developed to increase the country's foreign exchange receipts, expanding and flattening in employment, encourage regional development, improve well-being and prosperity people, enrich the national culture, and retaining the nation's personality for the sake of implementation of religious values, deepen friendship among Nations, fostering a love of the motherland, as well as maintaining the functionality and quality of the environment. 
Furthermore according to Muslim (2016) stated that development, tourism and regional development in the future, need better management, as it will bring more incam supports national development.

West Sumatra has beautiful environment and natural ecosystem. In West Sumatra there are many tourist attractions, if managed well will be able to bring the country's foreign exchange receipts, as well as the surrounding communities will be able to improve the economy. Therefore it was supposed the existing tourist attractions in West Sumatra in the manage well, and expected involvement of local government as a spearhead in developing the tourism industry greatly expected.

Bukitinggi city is one of the famous tourism destination in West Sumatra. There is a famous destination with beautiful natural view such as Ngarai Sianok (canyon), Jam Gadang, and Zoo. Another interesting tourist sights is "Lubang Japang", from the history of Japan during the colonial period remains. In addition it is Fort De Kock, this is a relic of the era of imperialism VOC.

The area of West Sumatra has a very rich culture and diverse is the one factor towing tourists. Among the famous culture in West Sumatra Province is Matriachat culture, embraced the lineage from the mother. In the West Sumatra matrilineal families boys in the family don't get the inheritance, and the girls got a treasure inherited from the mother's lineage. Based on power support those factors then certainly this area is very likely to be developed mainly in the field of tourism. The development of tourism has a value that is very strategic because it can develop their cultures and keep its natural potential, and the potential of tourism into economic activities in creating jobs and then imposes the welfare of society.

The development of tourism areas certainly not grown casually without an effort being undertaken. Among them is a huge factor of its influence in the development of tourist areas including availability of local Government much-needed facilities and infrastructure for the development of this sector and to become one of the flagship sector. So is the quality of the environment is an integral part of the tourist industry. For the developer and organizer of the tourism activities, environmental quality should get attention, including tourist-conscious society.

One of the influential factors in the framework of the development of the tourism industry in the town of Bukitinggi is traders souvenirs. There are souvenirs that traders in the city of Bukittinggi is still not ready to support the success of the tourism industry. Based on observations of researchers on 4 March 2017 souvenir merchants don't have the commitment to promote tourism in the regions. This souvenir traders observed yet can provide good service against tourists both local and foreign tourists, among them observed they offer merchandise at a price of expensive, even sometimes exists between them yet are hospitable to tourists both local and foreign tourists. In further observed souvenir traders are not ready to support the development of tourism in the city of Bukittinggi, including also other area communities in West Sumatra Province.

Based on problems in the pointed out, the researcher is interested in researching about participation of merchants souvenirs in the Bukittinggi City. Merchants souvenirs conscious intended as an accompaniment merchants souvenir promote Bukittinggi as a tourism city. Merchant souvenir conscious manifestation of them to participate providing input to the officer guarding the security, hygiene and order, improve the quality of the merchandise for souvenirs, as well as provide input to local governments for developing Bukittinggi as a tourism city.

This research aims to describes the conscious tourist merchant souvenir in Bukittinggi city. In a more detailed study of merchant souvenir conscious describes: (1) exploring the conscious of merchant souvenir; (2) describes the construction of a merchant souvenir conscious committed local government of Bukittinggi city. 
Merchant souvenir conscious aims to enhance the role of the merchant as well as souvenir for participating to promote tourist areas, including promoting Bukittinggi city as a tourist destination. The role of the merchant as well as souvenir in the shape of weld's attitude, behavior to host friendly and to improve the image, quality tourism products and services that are based on or improve the implementation of the Sapta Pesona (safe, orderly, clean, cool, beautiful, and memories). Sapta pesona is a condition that must be realized in order to attract the tourist visiting the area. For it must be created in a beautiful dazzle visitors, anytime and anywhere and especially in tourist destination so appealing and comfortable, happy to live longer and feel satisfied and gave a wonderful memories in his life.

Based on what has been described above there are seven tourist attraction elements that can affect the desire of visiting tourists who make it taste for longer stays in the tourist destination. Three elements of Sapta Pesona made targets need to be embodied in an attempt to improve the national discipline, secure, orderly and clean. The seven elements in Sapta Pesona, according to Dirjen Pariwisata (1994) as follows:

Secure, tourists would love to visit this place when they felt be safe, peaceful, not afraid, protected and free from acts of crime, violence, threats, such as extortion, fraud, etc. Free from infectious diseases and developing other harmful diseases. Furthermore avoid accidents by equipment and facilities that are less good, such as transportation, equipment for food and beverage, elevator equipment, recreation or sports. Factors that also need to be aware of is spared from interference by society, among others, in the form of forgery by hawkers hand ignorant, and speech. So security is a condition that gives an atmosphere of tourism for travellers, free of fear and not be worry would be the salvation of the soul, body and possessions, free from the threat of disorder and violence.

The condition is something that is highly coveted by everyone including tourists. The condition was reflected from a smooth, sleek and uncluttered and shows a high discipline in all facets of community life, such as the traffic is orderly, regular and smooth transport, tools come and depart on time. It did not seem people are crowding or snatched away to get or buy something that is needed. Later buildings and the environment laid out orderly and neat. Service in different areas carried out good and proper. The information obtained was not confusing travelers.

Travelers would felt welcome and comfortable when you were in places that are clean and healthy, such as: (1) clean environment both at home and in public places such as the hotel restaurants, public transport, places of recreation, a place to defecate, clean of trash, dirt and so on doodles; (2) cereal to eat and drink clean and healthy; (3) the provision of equipment such as cleaning spoon, plate, bed, sporting, tools and etc; and (4) clothing and appearance is neat and clean.

Cool, versatile surroundings green, fresh, neatly giving mood or circumstance is cool, comfortable and peaceful. The desired coolness did not just has to be outdoors or buildings, but also in a room, e.g., work/study, dining room, bedroom etc. Participate actively nurture environmental sustainability and the greening has been done by the Government or society. Be an active for advocating and pioneered the local community in order to carry out maintaining hygiene, planting a variety of plants in the home page of each good for ornaments or plants that are beneficial to household, do tree planting/shady plants along the way in their respective environments, on the school and anothers. The purpose of keeping the assembly form the environmental sustainability. Decorate room study/work, living room, bedroom and other places with a variety of plants to decorate. Other efforts that could made our environment into a cold, clean, fresh and comfortable.

Beautiful, circumstances or atmosphere featuring an attractive environment and unsightly called beautiful. Beautiful can be seen from various facets, such as in terms of colour, layout, shape or style of spatial and motion matching and alignment, so that gave you a nice impression and nice to look at. Beautiful is always in line with the clean and orderly and an integral part of the environment either in 
the form of the creation of God as well as the work of man. Because it is our obligation to keep the environment so that a sustainable and able to enjoyed by the people. Things that need to be done in connection with: (a) initiating and urge people to maintain sustainability and beauty that exists, and (b) invite the community to organize your environment on a regular basis, orderly and harmonious.

Welcoming, is an attitude and behavior of person that shows familiarity, polite, loves to help, like smile, and enticing. Friendly is the character and culture of the nation of Indonesia generally, always respecting the guests and can be a good host. This suave demeanor is one of the attraction for tourists and must be maintained properly. Things that need to be done amongst other souvenirs merchants: (a) invites people to demonstrate the attitude as a good hostess, friendly and willing to help and serve the tourists, and (b) help to provide information about custom that need to be followed the tourists with a polite and friendly manner, (c) sell goods to tourists with the price according to the quality of the goods, as well as serving with friendly buyers.

Then the memories, is the impression that sticks firmly in the memories and feelings of a person caused by the experience acquired. Memories can be a beautiful and fun, but can also be unpleasant. Memories are like to be embodied in the memories and feelings travellers from tourism experience in Indonesia, by itself is a beautiful and fun, this beautiful memories can also be created, among others: (a) comfortable, clean accommodation and healthy, fast service, and friendly atmosphere, which reflects the typical of the area in the form and style of the building and decoration, (b) art and cultural attractions of the area is typical and charming, be it in the form of dance, sound art, a variety of ceremonies, (c) typical regional food and drinks are delicious, with an attractive appearance and presentation. Food and drink is one attraction that is strong and can be used as identity (identity), and (d) the small souvenirs that reflect typical regional characteristics, high quality, easy to carry, and at an affordable price, has its own sense and made into evidence or memories of the visit of a person to some places. The participation an accompaniment of traders selling quality souvenirs souvenirs, as well as describing the characteristic area of West Sumatra it is desirable.

\section{Methods}

The methods used in the research was the qualitative method, with the intention to find a wide and deep about: (1) knowingly tourist souvenirs for merchants in Bukittinggi City); (2) the construction of a merchants souvenir conscious by the Government of Bukittinggi city. In this research a variety of factors associated with the increase in tourism to merchant souvenir include: local government, tourism and cultural areas, as well as souvenirs, the merchant community that can provide information about souvenir trader's involvement in promoting tourism. Then Creswell (2009) suggests that a qualitative approach can be used when we want to learn about an issue or a problem by looking at a variety of things related to the problem of the actual conditions.

The subject of this research is the merchant souvenirs that are in Bukittinggi city among other forts (Fort De Kock), Canyon (Ngarai Sianok), Lubang Japang, Jam Gadang, and zoos. Subject retrieval techniques research will be done by the method of purposive sampling and snowball. The data will be analyzed using the interactive analysis model Miles \& Huberman (1992) and internal environment analysis-external.

Data collection techniques used in this research are: (a) in-depth interviews to traders souvenirs to obtain data on tourism in the form of conscious companion to participate for the tourist sites in the city of Bukittinggi city tours; (b) the interviews done to Bukittinggi city to obtain data about the construction of merchant souvenirs conscious; (c) as the complement of the data carried out interviews to the surrounding communities of interest who knows about their participation merchants souvenir are an accompaniment to promote tourist sites in Bukittinggi city.

The validity test of the data in this research is by triangulation of the extension of the involvement of researchers in the field, if there is data that is found where it is still lacking and need to do some 
research re against objects that are interviewed and observed (Richey \& Klein, 2007; Sugiyono, 2011). Then triangulated the source may be made to parties who know the merchants souvenir in Bukittinggi. local government, head of the regional tourism development, expert tourism, and an expert on education.

\section{Results and Discussion}

Tourist conscious behavior research findings for merchants souvenirs intended from research results is participation, can also be a donation effort to accomplish a purpose and that is to achieve progress tours in certain areas. Research findings describing the part of traders conscious tourist souvenirs have already begun to portray an accompaniment to participate merchants souvenir in terms of providing advice, input, opinions to the Government or to a fellow merchant souvenirs or input to the community to achieve progress in the field of tourism in Bukittinggi city. The merchant souvenir conscious should be increased, since it would encourage tourists to visit tourism city in West Sumatra, as well as public awareness for open to tours will support Indonesia's economic growth. As revealed Fitriana (2017), the economic development of the year 2025 creative in the quality of governance, education and awareness in the area of tourism developer principals of Sumatra, including in Indonesia.

In connection with it tourist-conscious in this respect could be in the form of participating keep order, cleanliness and security of the surroundings of the place to trade. Participation is the indication an accompaniment by some merchants souvenirs in order to advance the Bukittinggi city, in this case the merchant keep order selling, with attention to the beauty of the place they are selling. Environment where merchants sell to expect clean so that it can maintain a healthy lifestyle, and the buyers will feel happy and they will be more comfortable in a clean environment. Avoid unwanted odors, allowing travelers enjoy staying in tourist areas. Security is a very important factor in care.

The behavior of orderly, clean, as well as maintaining security is the behavior that needs to be grown, nurtured and realized in everyday life merchant souvenirs. Research findings describe a fraction of traders souvenirs already behave keep order, hygiene, as well as maintain the security. A very difficult problem is manifested is the behavior of the net, where it still looks rubbish scattered around the merchants souvenirs. Then place the small bowel movements and it still looks dirty and less volcanically active public hygiene officers to maintain the cleanliness of the facilities. In line with that tourism for the development of tourism required Sapta Pesona meant a condition that must be realized in order to attract tourists to visit, to a region or a specific area in our country (Dinas Pariwisata, Seni \& Budaya Provinsi Sumatera Barat, 2004). Things to note in order for the tourist area attracting foreign tourists or local is; security, cleanliness, order, beauty, cool, friendly, and have memories that are meant for tourists both local and foreign tourists.

Keep friendly behavior, appreciate tourists both local and foreign tourists. Friendly is good natured, and attract the favor of sweet language, spoken word and his love to hang out and fun. The attitude of the familiar which becomes the hallmark of our nation's heritage would be vacationers visiting constituents to our country.

Describing research findings that most of the merchant souvenir already behave kindly pointed out by merchant souvenirs, so local tourists and foreign tourists will be interested in buying the souvenirs are sold. Friendly behavior is behavior that's been there since the ancestors of the nation of Indonesia which is passed down to the next generation. The nation of Indonesia is famous for its hospitality to welcome guests, sweet said the language was an elegant.

Similarly, traders expected souvenir friendly buyer, well behaved, not abusive to the buyer. Behave fun in association with fellow travelers, as well as with the community around the place of 
merchants souvenirs. According to tourism agency the process of construction tourism community should be a process of educational discipline communities (Dinas Pariwisata, Seni \& Budaya Provinsi Sumatera Barat, 2004). Through the process of education of community attitudes and behaviour in the area of tourism must be friendly serving tourist, said good words and politely shown by the community, including the behavior of merchant souvenirs with friendly service in a it sells merchandise, thus fostering the motivation the tourists for buying.

The goods packaging for souvenirs in order to attract local and foreign tourists buying merchandise. One behavior that is essential in order to promote the merchant's souvenirs is the packaging of goods for souvenirs as attractive as possible. Research findings describing the merchants souvenir a small percentage have started to pack the merchandise well. First of all he saw shoppers to buy is the packaging. The more nice packaging goods increasingly interested them. Merchandise is wrapped with a neat, clean, will draw from on the open, dirty, and dusty. Behavior that is clean, neat, merchants must keep souvenirs, because with clean, tidy will cultivate the desire of people to buy goods souvenirs. In line with this expressed by Dinas Pariwisata, Seni \& Budaya Provinsi Sumatera Barat (2004), among the factors that encourage the development of the tourism industry is the skills of community for selling quality of goods, and accompanied by more mainstream our resident is welcoming and serving guests.

Keeping good communication between merchants souvenirs. Giving feedback to each other need to be done. Research findings describe a fraction of traders already give input about the pricing of goods according to the quality of the goods. Selling goods too expensive while the quality is lacking good will can be detrimental to the merchants themselves. The goods on display are certainly less successful or not a bid or purchase merchandise. For it is need for meetings between traders souvenirs so that goods sold interest tourists both local and foreign tourists.

Awareness to improve the quality of souvenirs are sold. Furthermore the behavior that should be owned by the merchant souvenirs is the awareness to improve the quality of the goods sold. Goods with good quality will attract buyers to buy souvenirs. The quality are low would discourage tourists to purchase goods offered.

Increase knowledge in order to help travelers get to know the sights of behavior need grown merchants souvenirs is providing friendly service, Merchant Souvenir could provided a good and true information about what attractions are there in the area. For example, in the Bukittinggi city introduced the tourism destination, so that local tourists it helpful regarding the information provided. Honesty in the merchants souvenir provide the information about tourism destination there are highly expected to help local/foreign tourists to visit the tourism destination. The presence of tourists will positively impact for the community and also for governments to be equally forthcoming material gains.

Foster the participation of tradesmen souvenir keeping facilities, cleanliness, order and security. Participation an accompaniment merchant souvenirs in keeping facilities, cleanliness, order and security is highly expected. Places of public facilities must be kept clean. For example, public toilets, the place of prayer, rest areas travelers should be maintained the cleaning. Problems that often happen to public facilities dirty, especially in toilet either in mosques, public places are often seen less maintained clean.

The next issue of cleanliness, orderliness is visible in the residence there is also found a dirty room, toilet lacking well-ordered. Souvenir merchants are expected to participate providing input to the giver of the services of the inn, to the community to keep the facilities cleanless, order and security so as to cultivate a high motivation for tourists visiting the area includes Bukittinggi is known as a tourist city. 
Provide input advice to local governments in maintaining cleanliness, order, and security. To progress in tourism activities smoothness and merchant souvenir in Bukittinggi provide input to local governments for special personnel hygiene to prepare the responsible for the cleanliness of the facilities that exist in tour around the city. With the power of cleanliness is expected-the cleanliness of public toilets as places of prayer maintained cleanliness, beauty, and at any time.

Giving feedback or suggestions were morale to local governments for making better the tourist areas. Merchants souvenir a small percentage participate in morale, provide input in the form of donations in the form of suggestions, opinions to the Government in order to materialize Bukittinggi as a tourism city. Donations morale given merchant souvenirs, namely in the form of support for the policy of the regional government on the implementation of Bukittinggi City.

Provide input to local governments in order to speed up the construction of Bukittinggi city merchant souvenir to speed up input for Bukittinggi city, including construction of public facilities such as the building of highways, bridges, wc, and etc. needs to be increased in purchasing to support an activities. The minibus driver in order to improve its hospitality to the local or foreign tourists.

Merchant souvenir were expected to have an awareness of the importance of promoting their destination might be of interest to local tourists, as well as foreign tourists. Most merchants souvenir never too expensive especially for a gift shop for tourists. The traders then expected the friendly in serving buyers. Tourist souvenirs to traders conscious will cause a high motivation for tourists to visit in the area of tourism. Friendliness, good nutrition and earthy will cause tourists to flock comes to attractions such as Bukittinggi city.

\section{Conclusions}

Based on the results of the study as described in the previous section, then the following expressed the following conclusions: (1) the description of a tourist souvenir traders conscious in Bukittinggi in terms of behavior or attitude of the neighborhood's merchant souvenir, describes some merchant giving souvenirs input to security officers in order to enhance security in tourist areas, maintaining the cleanliness of the facilities are provided local government of Bukittinggi city, keeping hygiene and the beauty of the tourist places of merchants souvenirs; (2) the description of the skills of merchant kept selling souvenirs, most merchants based on the quality of goods, merchant do stuff with good packing giving rise to nudge tourists buy souvenirs on offer; (3) the description of the communication between other merchant souvenir while maintaining good communication in order to improve the quality of the goods, the buyer's tourist behavior in terms of the bargaining price souvenirs.

Further research findings relating to the input, suggestions for souvenirs merchants to local governments to improve the tourist area in Bukittinggi city: (1) merchants souvenir a small percentage deliver advice to government area among them are expecting government improving the security of the city, the cleanliness of the city, as well as enhancing the beauty of the city; (2) the construction carried out by local governments against the merchant souvenirs, small traders suggested local governments still less built the merchants souvenirs. Coaching conducted in terms of venue rental for merchants souvenirs.

\section{References}

Creswell, J. W. (2009). Research Design Pendekatan Penelitian Kualitatif, Kuantitatif, dan Mixed. Yogyakarta: Pustaka Pelajar.

Dinas Pariwisata Seni \& Budaya Provinsi Sumatera Barat. (2004). Buku Panduan Penyuluhan Sapta Pesona \& Sadar Wisata. Padang: Dinas Pariwisata, Seni \& Budaya Provinsi Sumatera barat. 
Dirjen Pariwisata. (1994). Panduan Sadar Wisata I. Jakarta: Dirjen Pariwisata.

Fitriana, W. (2017). The Role of Triple Helix Actors for Agro-Tourism Development in West Sumatera. MIMBAR, 33(2), 217-225. Retrieved from

https://ejournal.unisba.ac.id/index.php/mimbar/article/download/2098/pdf

Miles, M. B., \& Huberman, M. A. (1992). Analisis Data Kualitatif. Jakarta: UI Press.

Muslim, A. (2016). Economic Community Empowerment Through Tourist Village Development. MIMBAR, 32(2), 343-352. Retrieved from

https://ejournal.unisba.ac.id/index.php/mimbar/article/download/1839/pdf

Richey, R. C., \& Klein, J. D. (2007). Design and Development Research: Methods, Strategies, and Issues. New Jersey: Eribaum Associats Inc.

Sugiyono. (2011). Metode Penelitian Kuantitatif, Kualitatif dan RED. Bandung: Alfabeta. 